\title{
Growth of the nasopharynx and adenoidal development in Brazilian subjects
}

\section{Crescimento da nasofaringe e desenvolvimento da adenóide em brasileiros}

\author{
Beatriz de Souza Vilella* \\ Oswaldo de Vasconcelos Vilella** \\ Hilton Augusto Koch***
}

\begin{abstract}
The purpose of this research was to study the growth of the nasopharynx and adenoid development. Lateral cephalometric radiographs obtained from 320 white Brazilian subjects between 4 and 16 years of age were used. All the participants were nose breathers and none of them had previously undergone adenoidectomy. Tracings were made from the radiographs and cephalometric measurements were performed. The results showed that adenoid sagital thickness is larger in the age group $4-5$ years and decreases progressively. There is a slight increase in the age group $10-11$ years, but afterwards the decrease continues. However, the nasopharyngeal free airway space does not decrease in the age group 10-11 years, despite the increasing thickness of the adenoid. This is attributable to the downward displacement of the hard palate, resulting in an increase of the free airway space due to growth. Although the nasopharynx follows a growth pattern similar to that of the rest of the body, adenoid tissue does not. Adenoidal development seems to differ from that of other lymphatic tissues, showing a peculiar pattern that can be revealed when hypertrophy due to infections and allergies is eliminated.
\end{abstract}

DESCRIPTORS: Nasopharynx; Adenoids; Radiography; Mouth breathing.

\begin{abstract}
RESUMO: O objetivo da pesquisa foi estudar o crescimento da nasofaringe e o desenvolvimento da adenóide. Foram utilizadas as radiografias cefalométricas de perfil obtidas de 320 indivíduos brasileiros brancos, cujas idades variavam entre 4 e 16 anos. Todos os participantes apresentavam respiração predominantemente nasal e não haviam sido submetidos previamente à adenoidectomia. A partir das radiografias foram feitos traçados cefalométricos, sobre os quais foram realizadas medições. Os resultados revelaram que a espessura sagital da adenóide é maior na faixa etária de 4 a 5 anos, regredindo, então, progressivamente, até a faixa etária de 10 a 11 anos, quando ocorre um leve aumento, voltando a diminuir em seguida. O espaço aéreo livre nasofaríngeo, entretanto, não diminui na faixa etária de 10 a 11 anos, mesmo diante do aumento da espessura da adenóide. Esse fato se deve ao deslocamento do palato duro para baixo, o que determina a ampliação do espaço aéreo livre em razão do crescimento. Apesar de a nasofaringe seguir um padrão de crescimento similar ao do resto do corpo, a adenóide não o segue. O desenvolvimento da adenóide parece ser diferente do dos demais tecidos de origem linfóide, apresentando um padrão peculiar que pode ser percebido quando se elimina a hipertrofia causada por infecções e alergias.
\end{abstract}

DESCRITORES: Nasofaringe; Adenóides; Radiografia; Respiração bucal.

\section{INTRODUCTION}

The posterior nasopharyngeal wall is covered by lymphoid tissue that often undergoes hypertrophy (adenoid) during the period prior to puberty. This adenoidal enlargement increases the chance of nasopharyngeal airway obstruction, which is particularly important, considering that mouth breathing resulting from nasal obstruction does not offer normal environmental conditions for the growth and development of the nasomaxillary complex ${ }^{1-3,11,13,14,17-19,21}$, pointing to an asso- ciation between mouth breathing and dentofacial deformities. Therefore, the relationship between the nasopharynx size and the adenoid size is cru$\mathrm{Cial}^{7,9,20}$.

For many years, it has been believed that the adenoid would present a growth pattern similar to that of other lymphoid tissues such as the appendix, the spleen and the thymus, reaching its maximum size just before puberty, showing subsequent atrophy ${ }^{16}$. Meanwhile, some authors have assured

* PhD, Private Practice.

** PhD, Department of Orthodontics, School of Dentistry, Fluminense Federal University.

*** PhD, Department of Radiology, School of Medicine, Federal University of Rio de Janeiro. 
Vilella BS, Vilella OV, Koch HA. Growth of the nasopharynx and adenoidal development in Brazilian subjects. Braz Oral Res 2006;20(1):70-5.

that adenoid tissue seems to have a specific growth potential $1^{9,15}$, and it is on this potential that hypertrophic reactions of nasorespiratory infections and allergies may be superimposed ${ }^{15}$.

Subtelny, Koepp-Baker ${ }^{15}$ (1956) concluded that its growth peak may be reached as early as 9 to 10 years of age and is sometimes evident as late as 14 to 15 years of age, showing atrophy after this time. Linder-Aronson, Leighton ${ }^{9}$ (1983) verified that adenoid tissue is larger at the age of 5 and, therefore, it does not follow the classic lymphoid growth curve.

In relation to sexual dimorphism, some authors ${ }^{5,9}$ stated that boys and girls show different patterns of nasopharyngeal growth and adenoid development.

Considering that a systematic abnormal way of breathing can lead to a succession of events that are detrimental to the developing child and that there are contradictory conclusions based on the results of previous studies, it would be important to do a research in order to study the nasopharynx growth and the adenoid development.

\section{MATERIAL AND METHODS}

The present retrospective study was conducted in accordance with the October $10^{\text {th }}, 1996$, National Health Council's resolution 196, and monitored by the Ethic Research Committee, Fluminense Federal University.

The sample consisted of 320 white Brazilian children (160 boys and 160 girls) from the Department of Orthodontics, School of Dentistry, Fluminense Federal University (UFF), Niterói City, RJ, Brazil. These patients were divided into six groups: $4-5$ years (30), $6-7$ years (50), $8-9$ years (60), $10-11$ years (60), $12-13$ years (60), and $14-15$ years (60). Subjects that had systematically used either topical or systemic medication for the nose were excluded from the sample, as well as those who had undergone adenoidectomy. As a selection criterion, subjects should breathe predominantly through the nose.

\section{Clinical evaluation}

Children were submitted to history taking and clinical examination. The clinical examination consisted of three tests to identify mouth breathers. The first test was performed in the following way: the patient was asked to close the lips and breathe deeply through the nose. Nose breathers normally demonstrate a good reflex control of the alar muscles, which regulate the size and contour of the external part of the nostrils that dilate while inspiring. Nose breathers, even with temporary nasal congestion, will demonstrate reflex alar contraction and dilation of the nostrils during voluntary inspiration. Mouth breathers, even when able to breathe through the nose, do not alter the size and contour of the nostrils, and occasionally, contract nose openings when they inspire ${ }^{10}$.

Mouth or nose breathing was recorded by the second test by holding a cold dental mirror alternately in their front. The patient was seated in a relaxed position with the head upright. Ability to breathe through the nose was tested for each nasal passage separately, by observing whether the subject could breathe calmly for 30 seconds when one of the nostrils was closed by pressure, with the mouth closed ${ }^{8}$.

The third test was a functional test. Patients were asked to bend their knees 10 times in rapid succession. If, directly afterwards, they were able to continue breathing without difficulty, calmly, through the nose for 30 seconds, they were classified as pure nose breathers ${ }^{8}$.

\section{Cephalometric evaluation}

Subjects were evaluated with standard lateral cephalometric radiographs. These radiographs were taken with the child's head immobilized in a wall-mounted cephalostat and oriented to the Frankfort horizontal plane.

The head was fixed so that the median plane was parallel to the film. All the measurements were performed by the first author.

\section{Reference points}

The studied cephalometric reference points were as follows:

- $\mathrm{Ba}$ (Basion) - the most posteroinferior point on the clivus of os occipitale;

- Ptm (Pterygomaxillare) - intersection between the nasal floor and the posterior contour of the maxilla;

- S (Sella) - centre of the sella turcica;

- So - midpoint on the line joining $\mathrm{S}$ and $\mathrm{Ba}$;

- $\mathrm{ad}_{2}$ - intersection of the posterior nasopharyngeal wall and the Ptm-So line.

\section{Measurements}

The following measurements were made: 
Vilella BS, Vilella OV, Koch HA. Growth of the nasopharynx and adenoidal development in Brazilian subjects. Braz Oral Res 2006;20(1):70-5.

- Ptm-ad $-\mathrm{d}_{2}$ - linear distance from the Ptm point to the $\mathrm{ad}_{2}$ point, in $\mathrm{mm}$, representing the nasopharyngeal airway space;

- $\operatorname{ad}_{2}$-So - linear distance from the $\mathrm{ad}_{2}$ point to the So point, in $\mathrm{mm}$, representing adenoid thickness;

- Ptm-So - linear distance from the Ptm point to the So point, in $\mathrm{mm}$, representing the sagital depth of the bony nasopharynx in a higher level;

- $\mathrm{ad}_{2}$-So/Ptm-So - ratio between adenoid thickness and the bony nasopharynx depth, obtained by dividing the $\mathrm{ad}_{2}$-So measurement by the Ptm-So value;

Linear distances (Figure 1) were measured with a digital caliper (Starret, São Paulo, Brazil), serial number 001296.

\section{Statistical analysis}

The method error (o') for intra-individual measurements was calculated with the following formula:

$$
o^{\prime}=\sqrt{\frac{\sum d^{2}}{2 n}}
$$

where $d$ is the difference between two measurements and $n$ is the number of double determinations.

Calculations were also made for arithmetic means $(\bar{\chi})$ and standard deviations (SD).

Student's $t$ test was used for testing the differences between means. A probability level of $1 \%$ was adopted $(\mathrm{p}<0.01)$.

\section{RESULTS}

The intra-examiner error in determining the four measurements values used in this study was calculated using 30 randomly selected cases. It was found that the method error was $0.71 \mathrm{~mm}$ for the Ptm-ad ${ }_{2}$ measurement, $0.78 \mathrm{~mm}$ for the $\mathrm{ad}_{2}$-So measurement, 0.02 for the $\mathrm{ad}_{2}$-So/Ptm-So ratio and $0.98 \mathrm{~mm}$ for the Ptm-So measurement. Therefore, the intra-examiner method error was of little importance in this study.

Means and standard deviations for Ptm- $\mathrm{ad}_{2}$, $\mathrm{ad}_{2}$-So, $\mathrm{ad}_{2}-$ So/Ptm-So and Ptm-So variables for the six age groups are presented in Table 1 . The nasopharyngeal airway space expressed by the $\mathrm{Ptm}-\mathrm{ad}_{2}$ linear distance presented increasing values between 4 and 16 years of age. Adenoid thick-

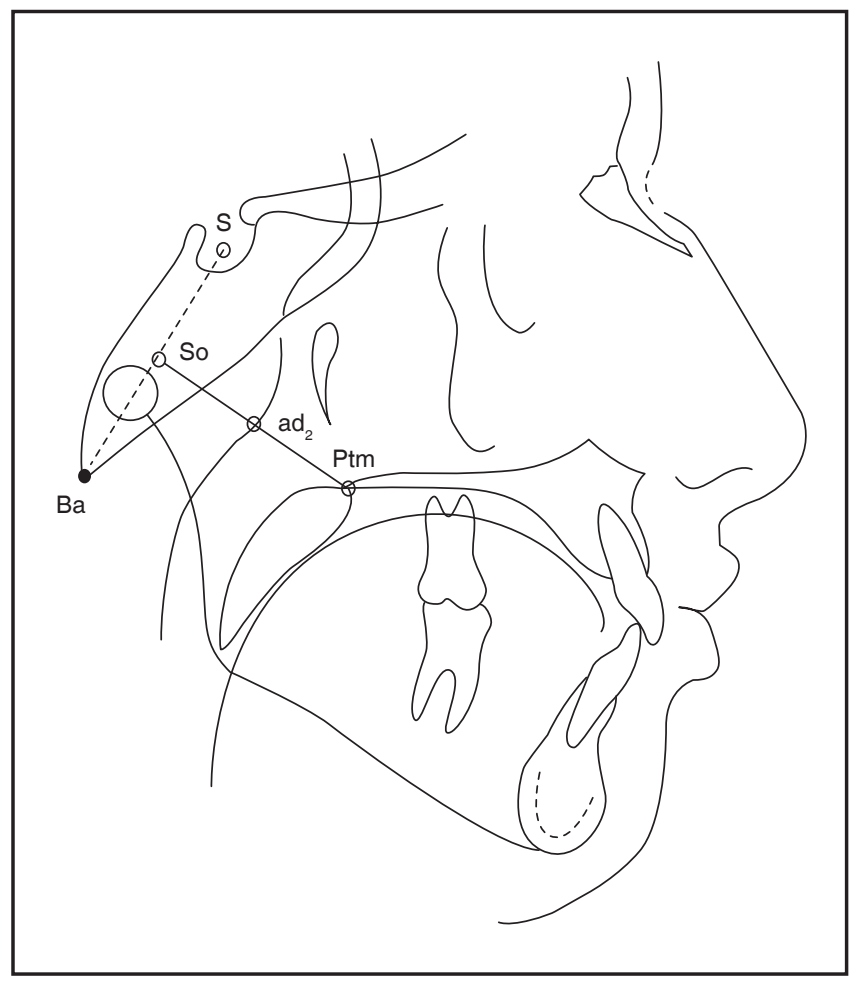

FIGURE 1 - Cephalometric tracing with the Ba, Ptm, S, So and $\mathrm{ad}_{2}$ reference points and the Ptm-ad $2, \mathrm{ad}_{2}-\mathrm{So}$ and Ptm-So linear measurements.

ness expressed by the $\mathrm{ad}_{2}$-So linear distance was larger in the age group $4-5$ years and decreased subsequently until the age group of $8-9$ years. There was a slight increase in the age group 10 - 11 years and the decrease continued from then on. The ratio between adenoid thickness and the bony nasopharynx depth decreased from 4 to 16 years of age. The bony nasopharynx depth expressed by the Ptm-So linear distance presented increasing values between 4 and 16 years of age, which suggests that the nasopharynx becomes larger with growth.

In Table 2, it can be seen that the arithmetic means of the $\mathrm{ad}_{2}$-So and Ptm-So variables are significantly higher for boys in comparison to girls in the age group $14-15$ years.

\section{DISCUSSION}

For orthodontists, it is of utmost importance to assess the patient's ability to breathe through the nose, since the damaging consequences of mouth breathing have already been appropriately reported in literature ${ }^{1-3,11,13,14,17-19,21}$. Nevertheless, there are few and disputed studies about 
Vilella BS, Vilella OV, Koch HA. Growth of the nasopharynx and adenoidal development in Brazilian subjects. Braz Oral Res 2006;20(1):70-5.

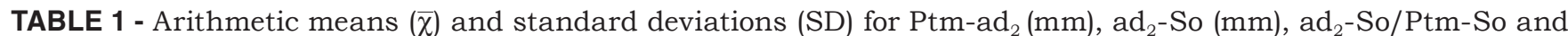
Ptm-So $(\mathrm{mm})$ measurements according to age group.

\begin{tabular}{c|c|c|c|c|c|c|c|c|c}
\hline \hline \multirow{2}{*}{$\begin{array}{c}\text { Age } \\
\text { group }\end{array}$} & \multirow{2}{*}{$\mathrm{n}$} & \multicolumn{2}{|c|}{ Ptm- $^{2}$} & \multicolumn{2}{c|}{$\mathrm{ad}_{2}$-So } & \multicolumn{2}{c|}{$\mathrm{ad}_{2}$-So/Ptm-So } & \multicolumn{2}{c}{ Ptm-So } \\
\cline { 3 - 10 } & & $\bar{\chi}$ & $\mathrm{SD}$ & $\bar{\chi}$ & $\mathrm{SD}$ & $\bar{\chi}$ & $\mathrm{SD}$ & $\bar{\chi}$ & $\mathrm{SD}$ \\
\hline $04-05$ & 30 & 12.47 & 2.79 & 25.10 & 3.17 & 0.67 & 0.07 & 37.55 & 2.35 \\
\hline $06-07$ & 50 & 14.24 & 2.16 & 24.36 & 2.24 & 0.63 & 0.05 & 38.73 & 1.97 \\
\hline $08-09$ & 60 & 16.21 & 2.42 & 23.51 & 2.93 & 0.60 & 0.05 & 39.72 & 3.18 \\
\hline $10-11$ & 60 & 17.55 & 2.74 & 24.03 & 2.83 & 0.58 & 0.06 & 41.58 & 2.87 \\
\hline $12-13$ & 60 & 18.77 & 3.06 & 23.81 & 2.22 & 0.56 & 0.05 & 42.86 & 2.97 \\
\hline $14-15$ & 60 & 20.36 & 2.67 & 22.63 & 3.08 & 0.52 & 0.05 & 42.98 & 3.61 \\
\hline \hline
\end{tabular}

TABLE 2 - Arithmetic means $(\bar{\chi})$, standard deviations (SD) and Student's $t$ test between the means of Ptm-ad $2(\mathrm{~mm})$, $\mathrm{ad}_{2}$-So $(\mathrm{mm}), \mathrm{ad}_{2}$-So/Ptm-So and Ptm-So $(\mathrm{mm})$ measurements for male $(\mathrm{M})$ and female $(\mathrm{F})$ subjects, according to age group.

\begin{tabular}{|c|c|c|c|c|c|c|c|c|c|c|}
\hline & \multicolumn{5}{|c|}{ Ptm-ad 2} & \multicolumn{5}{|c|}{$\mathrm{ad}_{2}$-So } \\
\hline & \multicolumn{2}{|c|}{ M } & \multicolumn{2}{|c|}{ F } & \multirow{2}{*}{$\mathrm{p}$} & \multicolumn{2}{|c|}{ M } & \multicolumn{2}{|c|}{$\mathrm{F}$} & \multirow{2}{*}{$\mathrm{p}$} \\
\hline & $\bar{\chi}$ & SD & $\bar{\chi}$ & SD & & $\bar{\chi}$ & SD & $\bar{\chi}$ & SD & \\
\hline 04-05 & 12.29 & 3.09 & 12.64 & 2.65 & 0.742 & 25.65 & 3.73 & 24.56 & 2.52 & 0.356 \\
\hline 06-07 & 14.62 & 1.98 & 14.21 & 2.37 & 0.509 & 24.33 & 2.29 & 24.39 & 2.24 & 0.926 \\
\hline 08-09 & 16.29 & 2.29 & 16.13 & 2.57 & 0.799 & 24.30 & 2.53 & 22.72 & 3.13 & 0.015 \\
\hline $10-11$ & 17.66 & 2.52 & 17.44 & 2.98 & 0.759 & 24.35 & 2.47 & 23.71 & 3.16 & 0.386 \\
\hline $12-13$ & 19.13 & 3.48 & 18.42 & 2.57 & 0.372 & 23.70 & 2.42 & 23.91 & 2.04 & 0.718 \\
\hline \multirow[t]{4}{*}{ 14-15 } & 20.56 & 2.56 & 20.16 & 2.80 & 0.566 & 23.68 & 3.06 & 21.57 & 2.76 & $0.007^{*}$ \\
\hline & \multicolumn{5}{|c|}{$\mathrm{ad}_{2}$-So/Ptm-So } & \multicolumn{5}{|c|}{ Ptm-So } \\
\hline & \multicolumn{2}{|c|}{ M } & \multicolumn{2}{|c|}{$\mathrm{F}$} & & \multicolumn{2}{|c|}{$\mathrm{M}$} & \multicolumn{2}{|c|}{$\mathrm{F}$} & \multirow{2}{*}{$\mathrm{p}$} \\
\hline & $\bar{\chi}$ & $\mathrm{SD}$ & $\bar{\chi}$ & SD & p & $\bar{\chi}$ & SD & $\bar{\chi}$ & SD & \\
\hline 04-05 & 0.67 & 0.08 & 0.66 & 0.06 & 0.701 & 37.94 & 2.25 & 37.16 & 2.46 & 0.373 \\
\hline 06-07 & 0.63 & 0.06 & 0.63 & 0.05 & 1.000 & 38.66 & 1.92 & 38.80 & 2.06 & 0.402 \\
\hline 08-09 & 0.60 & 0.05 & 0.59 & 0.05 & 0.442 & 40.59 & 2.95 & 38.84 & 3.21 & 0.994 \\
\hline $10-11$ & 0.58 & 0.05 & 0.58 & 0.06 & 1.000 & 42.01 & 2.15 & 41.15 & 3.42 & 0.248 \\
\hline $12-13$ & 0.55 & 0.05 & 0.57 & 0.05 & 0.127 & 43.38 & 3.25 & 42.34 & 2.62 & 0.178 \\
\hline $14-15$ & 0.53 & 0.05 & 0.51 & 0.06 & 0.166 & 44.21 & 4.12 & 41.75 & 2.54 & $0.007^{*}$ \\
\hline
\end{tabular}

* = Statistical significance at probability level of $1 \%$.

the growth pattern of the nasopharynx and about the adenoid growth cycle. In the present investigation, both were studied with the aid of lateral cephalometric radiographs. The sample selected consisted of nose-breathing white Brazilian, aged between 4 and 16 years, and was divided according to participants' age. Two measurements proposed by Linder-Aronson, Leighton ${ }^{9}$ (1983) were used together with the $\mathrm{ad}_{2}$-So/Ptm-So ratio and the PtmSo linear distance in order to allow the authors to achieve the research's purposes.
The Ptm- $\mathrm{ad}_{2}$ measurement's mean values show that the nasopharyngeal airway space is narrower in the age group $4-5$ years, and that an increase occurs subsequently. A previous study ${ }^{20}$ has shown that this measurement presents a perfect agreement with the endoscopic diagnosis. Therefore, it can be routinely used to evaluate nasopharyngeal airway obstruction. In other works, some authors ${ }^{9,12}$ verified that its smallest value was found at 5 years of age, which is in consonance with the current findings. However, they also found decreasing values between 8 and 10 
Vilella BS, Vilella OV, Koch HA. Growth of the nasopharynx and adenoidal development in Brazilian subjects. Braz Oral Res 2006;20(1):70-5.

years of age, which could not be noticed in the present research.

Examining ad $_{2}$-So measurement's mean values, it could be observed that thickness of the adenoid is larger in the age group $4-5$ years, showing subsequent decrease. This is in accordance with several authors' findings ${ }^{4-6,9,12}$.

The present findings, however, do not support Subtelny, Koepp-Baker's ${ }^{15}$ conclusions (1956) that the adenoidal growth peak may be reached between 9 and 15 years of age, atrophying subsequently.

Still in relation to the $\mathrm{ad}_{2}$-So measurement, it could be noticed that the adenoid showed a slight increase in the age group $10-11$ years, and then the decrease continued. This phenomenon had already been described by other researchers ${ }^{9,12}$, who imputed it to the influence of sexual hormones at puberty.

The $\mathrm{ad}_{2}$-So/Ptm-So ratio was introduced because the adenoidal size in relation to the bony nasopharynx can be considered more important than its absolute size for respiratory pattern evaluation. This ratio was larger in the age group $4-5$ years, then it diminished progressively until the age group 14 - 15 years. Fujioka et al. ${ }^{4}$ (1979) found the largest adenoid/nasopharyngeal space ratio at 4 years and 6 months, and the smallest at 15 years and 6 months of age, which is quite in accordance with the present findings.

The bony nasopharynx depth expressed by the Ptm-So linear distance was considered relevant to this research as it allows mensuration at the same higher nasopharyngeal level in which the airway space and the adenoidal thickness are measured. This distance increased from the age group $4-5$ years to the age group $14-15$ years of age. The increasing depth of the bony nasopharynx can help to explain the apparent contradiction between the nasopharyngeal free airway space increase as well as that of the adenoid thickness in the same age group $10-11$ years. From $8-9$ to $10-11$ years, the bony nasopharynx depth increased $1.86 \mathrm{~mm}$,

\section{REFERENCES}

1. Alcazar NMPV, Freitas MR, Janson G, Henriques JFC, Freitas KMS. Estudo cefalométrico comparativo dos espaços naso e bucofaringeo nas más oclusões Classe I e Classe II, divisão 1, sem tratamento ortodôntico, com diferentes padrões de crescimento. Rev Dent Press Ortodon Ortop Facial 2004;9:68-76. while the adenoidal thickness increased only $0.52 \mathrm{~mm}$. The difference between the two values, therefore, represents the airway space increase. Indeed, it has already been reported that, due to growth, the hard palate and, as a consequence, the Ptm point is displaced downward, resulting in an adequate airway space for nasorespiratory needs, even when the adenoidal thickness is increasing $^{10,15}$.

When the sample was divided according to the subjects' gender, it was noticed that for boys the bony nasopharynx was significantly higher in comparison to girls in the age group $14-15$ years. It could be seen that male subjects demonstrated growth until the age group $14-15$ years, while the maximum nasopharyngeal capacity in females was achieved in the age group $12-13$ years. These findings seem to be in accordance with what was stated by some authors ${ }^{5,9,12}$ that the nasopharynx growth follows a sexually determined pattern, similar to that of the rest of the skeleton.

Results also show that, for boys, the adenoidal thickness was significantly higher in comparison to that of girls in the age group $14-15$ years. It is very interesting to observe that the adenoidal tissue continues decreasing, even after the maximum nasopharyngeal capacity is achieved by females. Since male subjects demonstrate growth until the age group $14-15$ years, the last period analysed, it is not known whether the same phenomenon occurs in boys.

\section{CONCLUSION}

The present findings support the statement that although the nasopharynx follows a growth pattern similar to that of the rest of the body, adenoidal tissue does not. Adenoidal development seems to differ from that of other lymphatic tissues, showing a peculiar pattern that can be revealed when hypertrophy due to infections and allergies is eliminated.

2. Bresolin D, Shapiro PA, Shapiro GG, Chapko MK, Dassel S. Mouth breathing in allergic children: its relationship to dentofacial development. Am J Orthod 1983;83:334-9.

3. Faria PTM, Ruellas ACO, Matsumoto MAN, Anselmo-Lima WT, Pereira FC. Dentofacial morphology of mouth breathing children. Braz Dent J 2002;13:129-32. 
Vilella BS, Vilella OV, Koch HA. Growth of the nasopharynx and adenoidal development in Brazilian subjects. Braz Oral Res 2006;20(1):70-5.

4. Fujioka M, Young LW, Girdany BR. Radiographic evaluation of adenoidal size in children: adenoidal-nasopharyngeal ratio. AJR Am J Roentgenol 1979;133:401-4.

5. Handelman CS, Osborne G. Growth of the nasopharynx and adenoid development from one to eighteen years. Angle Orthod 1976;46:243-59.

6. Handelman CS, Pruzansky S. The size of the adenoids in normal and C. P. I. children. Presented at the IADR, Washington, DC; 1967.

7. Linder-Aronson S. Adenoids - Their effect on mode of breathing and nasal airflow and their relationship to characteristics of the facial skeleton and the dentition. A biometric, rhino-manometric and cephalometro-radiographic study on children with and without adenoids. Acta Otolaryngol Suppl 1970;265:1-132.

8. Linder-Aronson S, Bäckström A. A comparison between mouth and nose breathers with respect to occlusion and facial dimensions. Odontol Revy 1960;11:343-75.

9. Linder-Aronson S, Leighton BC. A longitudinal study of the development of the posterior nasopharyngeal wall between 3 and 16 years of age. Eur J Orthod 1983;5:47-58.

10. Moyers RE. Ortodontia. $4^{\mathrm{a}}$ ed. Rio de Janeiro: Guanabara Koogan; 1991.

11. Netta MLSS, Maruo H, Vieira SR, Saga AY. Estudo cefalométrico comparativo das dimensões craniofaciais entre crianças respiradoras nasais e bucais, com maloclusão Classe II, divisão 1. J Bras Ortodon Ortop Facial 2004;9:41-7.

12. Preston CB, Tobias PV, Salem OH. Skeletal age and growth of the nasopharynx in the sagittal plane: a cephalometric study. Semin Orthod 2004;10:16-38.
13. Solow B, Kreiborg S. Soft-tissue stretching: A possible control factor in craniofacial morphogenesis. Scand J Dent Res 1977;85:505-7.

14. Solow B, Siersbaek-Nielsen S, Greve E. Airway adequacy, head postures and craniofacial morphology. Am J Orthod 1984;86:214-23.

15. Subtelny JD, Koepp-Baker H. The significance of adenoid tissue in velopharyngeal function. Plast Reconstr Surg 1956;17:235-50.

16. Tanner JM. The human growth curve. In: Harrison GA, Weiner JS, Tanner JM, Barnicot NA, editors. Human biology. Oxford: Oxford University Press; 1964. 310 p.

17. Tarvonen PL, Koski K. Craniofacial skeleton of sevenyear-old children with enlarged adenoids. Am J Orthod Dentofacial Orthop 1987;91:300-4.

18. Tourne LPM, Schweiger J. Immediate postural responses to total nasal obstruction. Am J Orthod Dentofacial Orthop 1996;110:606-11.

19. Vargervik K, Miller AJ, Chierici G, Harvold EP, Tower B. Morphologic response to changes in neuromuscular patterns experimentally induced by altered mode of respiration. Am J Orthod 1984;85:115-24.

20. Vilella OV, Vilella BS, Ianni Filho D, Karsten A, Monteiro AA, Koch HA et al. Evaluation of the nasopharyngeal free airway space based on lateral cephalometric radiographs and endoscopy. Orthodontics 2004;1(3):215-23.

21. Yamada $\mathrm{T}$, Tane $\mathrm{K}$, Miyamoto $\mathrm{K}$, Yamauchi $\mathrm{K}$. Influences of nasal respiratory obstruction on craniofacial growth in young Macaca fuscata monkeys. Am J Orthod Dentofacial Orthop 1997;111:38-43.

Received for publication on Jun 20, 2005

Sent for alterations on Oct 14, 2005

Accepted for publication on Jan 09, 2006 